\title{
Addition of sucrose on cryoprotectant solution of vitrification enhances the quality of Dorper sheep embryos produced in vivo
}

\section{Adição de sacarose na solução crioprotetora de vitrificação melhora a qualidade de embriões ovinos Dorper produzidos in vivo}

\author{
Alane Pains Oliveira do Monte'; João Bosco Loiola Filho'; \\ Thais Thatiane dos Santos Souza ${ }^{1}$; Mayara de Souza Miranda ${ }^{1}$; \\ Lívia Correia Magalhães ${ }^{1}$; Celso Henrique Souza Costa Barros²; \\ Ana Arlete de Amorim Silva²; Adriano Oliveira Santos ${ }^{2}$; \\ Aionne de Souza Leite Guimarães ${ }^{2}$; Jonathan Maia da Silva Costa²; \\ Pedro Humberto Félix de Sousa ${ }^{3}$; Daniel Maia Nogueira ${ }^{4}$; \\ Mabel Freitas Cordeiro ${ }^{5}$; Edilson Soares Lopes Júnior ${ }^{5^{*}}$
}

\begin{abstract}
This study aimed to evaluate the efficacy of adding sucrose in vitrification solution of ovine embryos produced in vivo. Forty Dorper ewes were selected and superovulated. Immediately prior to the embryo collection by laparotomy, a laparoscopy was performed to verify the superovulatory response. The recovered flushing was followed by embryo evaluation and embryos were divided in two experimental groups where embryos from Control group were submitted to a traditional vitrification protocol and embryos from Sucrose group to a modified vitrification protocol with sucrose. After warming, embryos were again divided regarding cryoprotectant removal (Indirect) or not (Direct). The embryo quality was classified as embryos of degrees I (excellent or good), II (regular), III (poor) and IV (dead or degenerate). It was also verified the homogeneity of mass, occurrence of embryonic mass retraction and rupture of pellucid zone. The results were expressed as percentages and were subjected to Chi-square test with $\mathrm{P}<$ 0.05 . The embryos vitrified in the presence of sucrose had lower proportions of lower-quality embryos after warming ( 22.20 vs. $44.50 \%$ ), higher percentages of homogeneous embryos after warming (63.89 vs. $38.89 \%$ ) while concerning other parameters there was no difference between these groups. It can be concluded that the addition of $0.4 \mathrm{M}$ sucrose during vitrification improves the embryo quality.
\end{abstract}

Key words: Cryopreservation, embryo, ewe, multiple ovulation, sugar

\footnotetext{
${ }^{1}$ Discentes de Mestrado do Curso de Pós-Graduação em Ciência Animal - CPGCA, Universidade Federal do Vale do São Francisco, UNIVASF, Petrolina, PE, Brasil. E-mail: alane.monte@univasf.edu.br; bosco_mev@yahoo.com.br; miranda.ms@hotmail.com; liviamagalhaes@yahoo.com.br

2 Discentes, Universidade Federal do Vale do São Francisco, UNIVASF, Petrolina, PE, Brasil. E-mail: thaisthatiane_souza@ hotmail.com; celso_bar@hotmail.com; anaarleteamorim@hotmail.com; adriano-vet23@hotmail.com; aionneveterinaria@ hotmail.com; jonathanmaiacosta@yahoo.com.br

${ }^{3}$ Prof., Universidade do Estado da Bahia, UNEB, Juazeiro, BA, Brasil. E-mail: pedrohumbertos@bol.com.br

${ }^{4}$ Pesquisador, Empresa Brasileira de pesquisa Agropecuária, Semiárido, Embrapa Semiárido, Petrolina, PE, Brasil. E-mail: daniel.nogueira@embrapa.br

5 Profs., Universidade Federal do Vale do São Francisco, UNIVASF, Petrolina, PE, Brasil. E-mail: mabel.cordeiro@univasf.edu. br; edilsonlopesjunior@yahoo.com.br

* Author for correspondence
} 


\title{
Resumo
}

\begin{abstract}
Este estudo objetivou avaliar a eficácia da adição de sacarose na solução de vitrificação de embriões ovinos produzidos in vivo. Foram selecionadas 40 ovelhas da raça Dorper as quais foram superovuladas. Imediatamente antes da colheita de embriões por laparotomia, uma laparoscopia foi realizada para verificar a resposta superovulatória. O lavado recuperado foi submetido à procura e avaliação de embriões e estes foram divididos em dois grupos experimentais, onde os embriões do Grupo Controle foram submetidos ao protocolo tradicional de vitrificação e os embriões do Grupo Sacarose a um protocolo modificado de vitrificação com sacarose. Após a descongelação, os embriões foram novamente divididos considerando a remoção (Indireto) ou não (Direto) do crioprotetor. A qualidade embrionária foi classificada como embriões de graus I (excelente ou bom), II (regular), III (pobre) e IV (morto ou degenerado). Foi também verificada a homogeneidade da massa, ocorrência de retração da massa e ruptura de zona pelúcida. Os resultados foram expressos em porcentagem e foram submetidos ao teste do Qui-quadrado com $\mathrm{P}<0.05$. Os embriões vitrificados na presença de sacarose apresentaram menores proporções de embriões de menor qualidade após a descongelação (22,20 vs. 44,50\%), e maiores percentuais de embriões homogêneos após a descongelação (63,89 vs. 38,89\%) enquanto com relação aos demais parâmetros não existiram diferenças entre grupos. Pode-se concluir que a adição de $0,4 \mathrm{M}$ de sacarose durante os procedimentos de vitrificação e descongelação beneficia a qualidade embrionária Palavras-chave: Açúcar, criopreservação, embrião, múltipla ovulação, ovelha
\end{abstract}

\section{Introduction}

The cryopreservation process requires dewatering of embryonic cells in order to avoid ice crystal formation and subsequent damage to the membranes. Cryoprotectants gain importance in this process because they interact with membranes, protecting them against physical and chemical stress caused by elevated concentrations of these solutions in cooling (SEIDEL JUNIOR., 1986).

Among the cryoprotectants, there are those called intracellular or permeable ones such as dimethylsulfoxide (DMSO) and glycerol as well as so-called extracellular or impermeable such as the macromolecules glucose, lactose and sucrose. The importance of intracellular cryoprotectant is decreasing the solidification point, favoring dehydration, which reduces the formation of ice crystals. This dehydration should not be abrupt and the addition of cryoprotectants is done gradually in most protocols (SEIDEL JUNIOR, 1996). The relevance of extracellular cryoprotectants is the stabilizing effect of the membrane (CROWE et al., 1983). In addition, they assist the entry of cryoprotectants permeable and they are therefore generally used in combinations (ALLER et al.,
1995). Saito et al. (1994) found a significant increase in the survival of bovine blastocysts produced in vitro with the addition of sucrose in the vitrification solution.

The vitrification is a simpler, faster and less expensive technique when compared to slow freezing (BARIL et al., 2001). However, the need for high concentrations of cryoprotectants can cause damage to cells by osmotic stress and chemical toxicity (PAPADOPOULOS et al., 2002) and to reduce the ability to reach the glassy state. Seeking to decrease these obstacles in vitrification process, several protocols have been developed using different cryoprotectants, such as ethylene glycol (GUIGNOT et al., 2006), DMSO (HONG et al., 2007), glycerol and propylene glycol (WERLICH et al., 2006). Furthermore, the addition of macromolecules such as sucrose or trehalose has been reported with the function of promoting a significant osmotic effect and it is also used for rehydration of embryos after warming (HURTT, 1999; ISACHENKO et al., 2003). However, Dattena et al. (2004) verified that the addition of sucrose did not promote positive results on pregnancy rates from vitrified embryos. 
After warming of vitrified embryos generally is carried out the cryoprotectants removal, since this technique requires a high concentration of the medium. However, with the development of mediums associating permeable and impermeable cryoprotectants which act by increasing the molarity of the solution and promote the glassy state at the same way that benefits the increase in hydrostatic (RALL, 1987), it is necessary to check the effectiveness of these protocols in preserving the embryo integrity.

These studies have been applied to embryos of different species and in several sheep breeds. Although Dorper is an important sheep breed promoting a significant improvement in the herd regarding meat deposition abeing characterized by having a good adaptability at semiarid areas, reports of embryos from Dorper ewes are scarce.

Furthermore, most studies developed are concentrated for embryos produced in vitro, although these have lower survival rates than those obtained from embryos produced in vivo (ISACHENKO et al., 2003; LIM et al., 2008). This is due to the physical characteristics more sensible of these embryos such as higher number of vacuoles (SHAMSUDDIN et al., 1992) and increased fragility of the zona pellucida (DUBY et al., 1997). However, Dattena et al. (2004) did not significant differences between ovine embryos produced in vivo or in vitro concerning embryo survival.

Therefore, the aim of this experiment was to evaluate the effectiveness of adding sucrose in vitrification solution of the Dorper sheep embryos produced in vivo before and after the cryopreservation process.

\section{Material and Methods}

\section{Animal ethics}

All animal protocols used in this studies were approved by the Ethics and Deontology Committee in Studies and Researches of the Universidade
Federal do Vale do São Francisco (Process 27051112/CEDEP/UNIVASF). Additionally, all studies were conducted according to the guidelines for the ethical use of animals in research.

\section{Period and location of the experiment}

This study was carried out from June to July, in 2012, during the end of breeding season. The experiment was conducted at the Experimental Station of Agricultural Development Company of Bahia, in Jaguarari, Northeastern Brazil, at $10^{\circ} 15^{\prime} 50^{\prime}$ S latitude, $40^{\circ} 11^{\prime} 45^{\prime \prime} \mathrm{W}$ longitude and altitude of $400 \mathrm{~m}$.

\section{Animals}

Forty Dorper ewes were selected with a mean Body Condition Score of 3 ( $0=$ extremely thin, 5 = obese) and they were between 3 and 5 years of age. As breeders, it was used two Dorper rams with proven fertility by andrologic examination previously performed.

All animals were subjected to a semi-intensive system of production where they spent part of the day on preserved Caatinga and, in the late afternoon, received in indoor facilities, Tifton hay (Cynodon spp.) ad libitum and commercial concentrated. The animals had also free access to clean water and mineral salt.

\section{Hormonal treatments and mating}

The estrous cycles were synchronized using intravaginal devices impregnated with $330 \mathrm{mg}$ of progesterone (CIDR-G ${ }^{\circledR}$, Pharmacia, Brazil), inserted for 14 days. Forty-eight hours before CIDR removal, it was started a superovulatory treatment which was composed for six decreasing doses $(50,5025,25,25$ and $25 \mathrm{mg})$ of NIH-FSH-P1 (Folltropin-V ${ }^{\circledR}$, Vetrepharm, Canada) administered intramuscularly every 12 hours. Beginning $12 \mathrm{~h}$ after CIDR removal, the ewes were observed every 
$4 \mathrm{~h}$ and for $72 \mathrm{~h}$ to establish the time of estrus onset. Ewes were hand mated at estrus onset and $24 \mathrm{~h}$ after that.

\section{Superovulatory response and embryo recovery}

Before embryo collection and five days after mating, feed and water were withheld from ewes for at least $24 \mathrm{~h}$. On the following day and immediately prior to embryo collection, ewes were subjected to a laparoscopy to visualize the ovulatory response, as described by Oldham and Lindsay (1980). Laparoscopy permitted to observe the ovaries and identify the female which was considered responsive to superovulation treatment or the female presenting at least five corpora lutea in both of ovaries (BARIL et al., 1995).

Immediately after laparoscopy, females responding superovulatory treatment were submitted to embryo recovery which was performed by laparotomy (BARIL et al., 1995) using the foley catheter, and $40 \mathrm{~mL}$ of PBS warmed at $37^{\circ} \mathrm{C}$ (DPBS ${ }^{\circledR}$, VITROCELL, Brazil), for each uterine horn.

\section{Evaluation of recovered embryos}

The flushing was placed into plastic petri plates and subjected to research of embryos in a stereomicroscope (SMZ 645®), Nikon, Japan) using a magnification from 40 to $70 \mathrm{X}$. Evaluation of characteristics of structures such as the stage of embryonic development and quality was made following the morphologic criteria of the International Embryo Transfer Society (ROBERTSON; NELSON, 2010). Immediately after recovery, embryos were evaluated and they were classified as embryos of degrees I (excellent or good), II (regular), III (poor) and IV (dead or degenerate). In addition, embryos were simultaneously classified according to the level extrusion embryonic (Low, Medium and High), level of homogeneity of the embryonic mass (Homogeneous, Heterogeneous and Slightly Heterogeneous) occurrence or not of embryonic mass retraction and rupture of pellucid zone.

\section{Vitrification and warming}

Ninety embryos from 24 donors were homogeneously distributed according to stages of embryonic development and grades of quality. The recovered embryos were divided into two groups regarding embryonic quality and stage, and then they were subjected to two different vitrification protocols. In the first (Control Group), embryos were immersed in three solutions every 5 minutes (DMPBS $+20 \%$ FCS, PBS $+20 \%$ FCS $+10 \%$ glycerol, and DMPBS $+20 \%$ FCS $+10 \%$ glycerol $+20 \%$ ethylene glycol) and for 30 seconds in a vitrification solution with DMPBS + 20\% FCS + $25 \%$ glycerol $+25 \%$ ethylene glycol. Embryos from Sucrose Group were included at the same solutions as those of the Control but the vitrification solution received 0.4 M sucrose (WERLICH et al., 2006). After last bath, the embryos were loaded into 0.25 $\mathrm{ml}$ straws with 20-30 $\mu$ l of vitrification solution and separated by two bubbles of the same solution (approximately $90 \mu \mathrm{L}$, each). Then the straws were sealed, identified and immediately immersed in liquid nitrogen (GUIGNOT et al., 2006).

In order to warm embryos, the straws were kept in contact with air for 10 s and they were then immersed in a water bath at $37^{\circ} \mathrm{C}$ for $20 \mathrm{sec}$. Then the embryos from each experimental group (Control and Sucrose) were again divided into two groups: Control Group (Indirect and Direct; Sucrose (Indirect and Direct). The embryos from Indirect Groups were immersed in solutions of $0.25 \mathrm{M}$ and $0.125 \mathrm{M}$ sucrose, for 5 minutes each in order to remove the cryoprotectant and then kept in DMPBS for 5 minutes and immediately evaluated. However, embryos from Direct Groups were held in DMPBS also for 5 minutes and, immediately after evaluated. 


\section{Statistical analysis}

Statistical analyses were conducted using the SPSS software (IBM SPSS, version 19.0, 2010, USA). Analysis of Variance (ANOVA) was used to determine the distribution (homogeneity of variance) for age, body weight and body condition score of donors between experimental groups (Indirect and Direct Control, Indirect and Direct Sucrose). These sources of variability were found to be not significant and, as such, were not reported. Descriptive statistics were presented for the following variables: number of freezable embryos (EMBC: Grades I and II); stage of embryonic development; proportions of embryos in each level of quality (grades I, II, III and IV), level extrusion embryonic (Low, Medium and High), level of homogeneity of the embryonic mass (Homogeneous, Heterogeneous and Slightly Heterogeneous) in the vitrification and warming protocol; percentage of retracted embryos during vitrification and percentage of embryos reexpanded after warming. The data expressed as percentages were subjected to Chi-square test. The results were expressed as percentage. The differences between groups were considered statistically significant at $\mathrm{P}<0.05$.

\section{Results and Discussion}

Concerning embryo quality and viability, it was observed that there was a prevalence of freezable embryos $(\mathrm{P}<0.001)$ or those qualified as excellent / good and regular $(72.93 \%)$ compared to no freezable embryos or classified as poor and dead / degenerated (27.07\%) (Figure 1).

Figure 1. Quality (Excelent or Good, Regular, Poor and Dead or Degenerated) of embryos produced in vivo from Dorper ewes. ${ }^{a, b, c, d}$ Different letters between quality grades indicate significant difference $(\mathrm{P}<0.001)$.

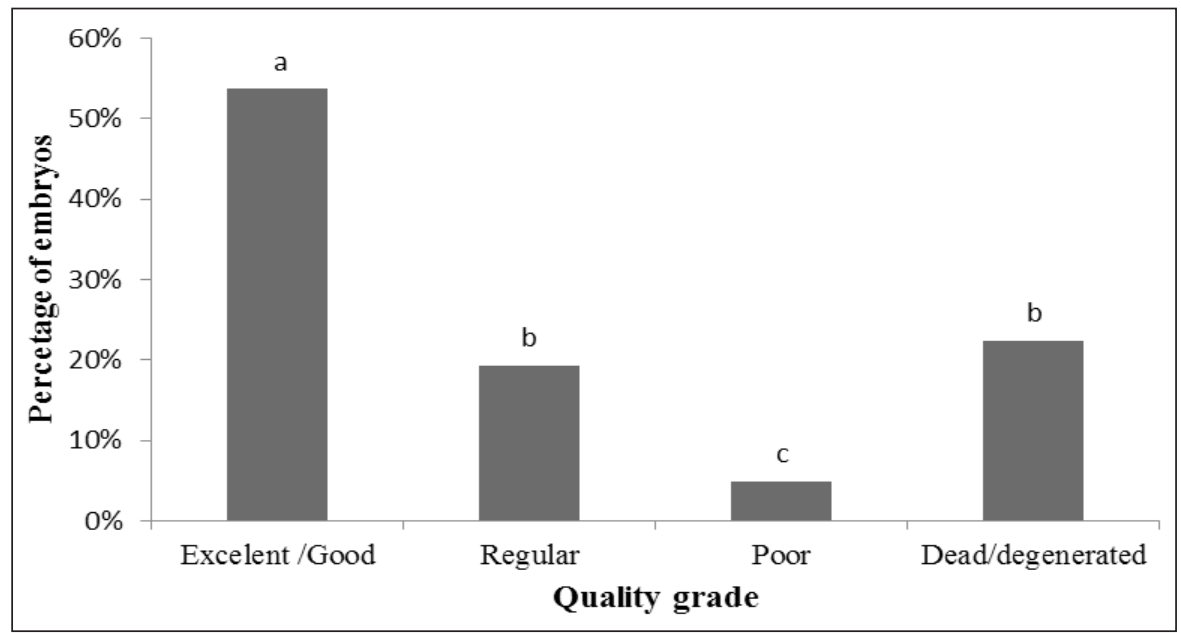

These data show that estrus synchronization and superovulation protocols used at present study were efficient for embryo production.

In the Table 1, it is presented the effect of the addition or not of sucrose at vitrification protocol and the using or not of sucrose to remove the cryoprotectant on in vitro embryo quality during the vitrification and warming process. 
Table 1. Quality grades (Excellent / Good, Regular, Poor and Dead; \%) of Dorper embryos produced in vivo and vitrified without sucrose and submitted (Indirect Control) or not (Direct Control) to cryoprotectant removal as well as with sucrose and submitted (Indirect Sucrose) or not (Direct Sucrose) to cryoprotectant removal, before vitrification and after warming processes.

\begin{tabular}{|c|c|c|c|c|c|c|c|c|}
\hline & \multicolumn{8}{|c|}{ Embryo quality } \\
\hline & \multicolumn{4}{|c|}{ Before vitrification } & \multicolumn{4}{|c|}{ After warming } \\
\hline & Excellent & Regular & Poor & Dead & Excellent & Regular & Poor & Dead \\
\hline $\begin{array}{c}\text { Indirect } \\
\text { Control(27) }\end{array}$ & $66,70(18)$ & $33,30(9)$ & 0,0 & 0,0 & $55,56(15)$ & $44,44^{\mathrm{a}}(12)$ & 0,00 & 0,00 \\
\hline $\begin{array}{c}\text { Direct } \\
\text { Control(27) }\end{array}$ & $70,40(19)$ & $29,60(8)$ & 0,0 & 0,0 & $55,56(15)$ & $44,44^{\mathrm{a}}(12)$ & 0,00 & 0,00 \\
\hline $\begin{array}{c}\text { Indirect } \\
\text { Sucrose(19) }\end{array}$ & $89,50^{A}(17)$ & $10,50^{\mathrm{B}}(2)$ & 0,0 & 0,0 & $78,94^{\mathrm{A}}(15)$ & $10,52^{\mathrm{bB}}(2)$ & $5,26^{\mathrm{B}}(1)$ & $5,26^{\mathrm{B}}(1)$ \\
\hline $\begin{array}{c}\text { Direct } \\
\text { Sucrose }(17)\end{array}$ & $70,60(12)$ & $29,40(5)$ & 0,0 & 0,0 & $64,71(11)$ & $35,29^{\mathrm{ab}}(6)$ & 0,00 & 0,00 \\
\hline
\end{tabular}

$\mathrm{A}, \mathrm{B}$ Values with capital letters within rows indicate significant difference $(\mathrm{P}<0.05)$.

${ }^{\mathrm{a}, \mathrm{b}}$ Values with small letters within columns indicate significant difference $(\mathrm{P}<0.05)$.

Regarding embryo quality during vitrification, it was observed a higher $(\mathrm{P}<0.05)$ proportion of excellent embryos only in the group of embryos vitrified in the presence of sucrose and subjected to removal of cryoprotectants (Indirect Sucrose), although no significant difference $(\mathrm{P}>0.05)$ was verified in other groups between grades of embryo quality and also there was no significant difference $(\mathrm{P}>0.05)$ between groups (Table 1). This process can be attributed to higher stability of membrane of frozen-thawed embryos on the presence of sucrose.

After warming, embryos vitrified in the presence of sucrose and subjected to cryoprotectant removal (Sucrose Indirect) were mostly ( $\mathrm{P}<$ $0.05)$ qualified as excellent as compared to other grades of embryo quality. There was, however, no significant difference $(\mathrm{P}>0.05)$ in the other groups between grades of embryo quality (Table 1). Also after warming and now comparing experimental groups within grades of embryo quality, it was observed a lower $(\mathrm{P}<0.05)$ percentage of regular embryos when these structures were vitrified in the presence of sucrose and submitted to cryoprotectant removal (Sucrose Indirect) comparing to the groups vitrified in the absence of sucrose Indirect Control and Direct Control where there was no removal of cryoprotectant. However, no significant difference $(\mathrm{P}<0.05)$ was observed between the proportions of regular embryos between groups frozen in the presence of sucrose (Indirect Sucrose and Direct Sucrose Groups) (Table 1).

Combining groups Indirect Control and Direct Control (Control Group) and groups Indirect Sucrose and Direct Sucrose (Sucrose Group), after warming, vitrification without sucrose (Control) had a rate significantly higher $(\mathrm{P}<0.05)$ of embryos classified as regular compared to those submitted to vitrification with sucrose (Sucrose) (44.5 vs. 22.2\%) (Fig. 2A)Regarding the effect of sucrose in the homogeneity of embryo mass after warming, the embryos vitrified with sucrose (Sucrose) and qualified as Homogeneous showed a significant superiority $(\mathrm{P}<0.05)$ when compared to those vitrified in the absence of sucrose (Control) (63.89 vs. $38.89 \%$ ). For no other parameter it was not observed a significant difference between the groups (Figure 2B). 
Figure 2. Effect of Sucrose in the grades of quality (A) (Excellent or Good, Regular, Poor and Dead or Degenerated) and homogeneity grades (Homogeneous, Slightly Heterogeneous and Heterogeneous of embryos produced in vivo from Dorper ewes.

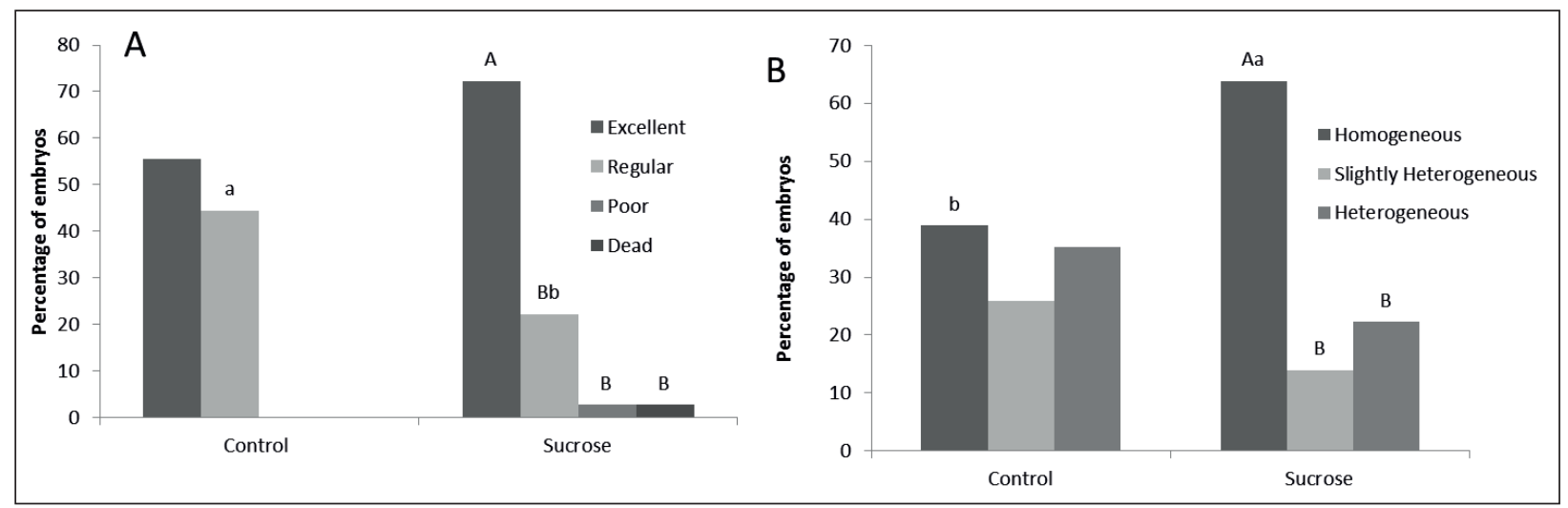

${ }^{\text {A, B }}$ Different capital letters indicate significant difference between quality grades.

${ }^{\mathrm{a}, \mathrm{b}}$ Different small letters indicate significant difference between groups.

In addition, before vitrification, it was observed higher $(\mathrm{P}<0.05)$ Homogeneous (HO) embryos than Heterogeneous (HE) ones. Furthermore, no significant difference $(\mathrm{P}>0.05)$ was observed between groups within the homogeneity levels (Table 2).

Table 2. Homogeneity grades (Homogeneous, Slightly Heterogeneous and Heterogeneous), of Dorper embryos produced in vivo and vitrified without sucrose and submitted (Indirect Control) or not (ontrol) to cryoprotectant removal as well as with sucrose and submitted (Indirect Sucrose) or not (Direct Sucrose) to cryoprotectant removal before vitrification and warming processes.

\begin{tabular}{|c|c|c|c|c|c|c|}
\hline & \multicolumn{6}{|c|}{ Embryo homogeneity } \\
\hline & \multicolumn{3}{|c|}{ Before vitrification } & \multicolumn{3}{|c|}{ After warming } \\
\hline & $\mathrm{HO}$ & LHE & $\mathrm{HE}$ & $\mathrm{HO}$ & LHE & $\mathrm{HE}$ \\
\hline Indirect Control & $51,85^{\mathrm{A}}(14)$ & $44,44^{\mathrm{A}}(12)$ & $3,71^{\mathrm{B}}(1)$ & $40,74^{\mathrm{ab}}(11)$ & $25,92(7)$ & $33,33(9)$ \\
\hline Direct Control & $70,37^{\mathrm{A}}(19)$ & $11,11^{\mathrm{B}}(3)$ & $18,52^{\mathrm{B}}(5)$ & $37,04^{\mathrm{b}}(10)$ & $25,92(7)$ & $37,04(10)$ \\
\hline Indirect Sucrose & $63,16^{\mathrm{A}}(12)$ & $26,31^{\mathrm{B}}(5)$ & $10,53^{\mathrm{B}}(2)$ & $68,42^{\mathrm{aA}}(13)$ & $15,79^{\mathrm{B}}(3)$ & $15,79^{\mathrm{B}}(3)$ \\
\hline Direct Sucrose & $64,7^{\mathrm{A}}(11)$ & $17,65^{\mathrm{B}}(3)$ & $17,65^{\mathrm{B}}(3)$ & $58,82^{\mathrm{abA}}(10)$ & $11,76^{\mathrm{B}}(2)$ & $29,41^{\mathrm{B}}(5)$ \\
\hline
\end{tabular}

A, B Values with capital letters within rows indicate significant difference $(\mathrm{P}<0.05)$.

${ }^{\mathrm{a}, \mathrm{b}}$ Values with small letters within columns indicatesignificant difference $(\mathrm{P}<0.05)$.

Already after warming, it was found that only in the groups vitrified in the presence of sucrose (Indirect and Direct Sucrose), there was predominance $(\mathrm{P}<0.05)$ of $\mathrm{HO}$ embryos compared to Slightly Heterogeneous (SHE) and HE ones (Table 3). Furthermore, regarding only $\mathrm{HO}$ structures, proportion of embryos vitrified in the presence of sucrose and subjected to removal of cryoprotectant
(Indirect Sucrose) was higher $(\mathrm{P}<0.05)$ than those vitrified in the absence of sucrose and not subjected to cryoprotectant removal (Direct Control) (Table 2).These data demonstrate that embryos vitrified on the presence of sucrose preserved their cellular morphology and this fact can be attributed to lower quantity of intracellular ice crystals in Sucrose Group. 
Table 3. Extrusion grades (High, Medium and Low), of Dorper embryos produced in vivo and vitrified without sucrose and submitted (Indirect Control) or not (Direct Control) to cryoprotectant removal as well as with sucrose and submitted (Indirect Sucrose) or not (Direct Sucrose) to cryoprotectant removal before vitrification and after warming processes.

\begin{tabular}{|c|c|c|c|c|c|c|}
\hline & \multicolumn{6}{|c|}{ Embryo extrusion } \\
\hline & \multicolumn{3}{|c|}{ Before Vitrification } & \multicolumn{3}{|c|}{ After Warming } \\
\hline & Low & Medium & High & Low & Medium & High \\
\hline Indirect Control & $81,48^{A}(22)$ & $14,81^{\mathrm{abB}}(4)$ & $3,71^{\mathrm{B}}(1)$ & $59,26^{\mathrm{A}}(16)$ & $29,63^{\mathrm{AB}}(8)$ & $11,11^{\mathrm{abB}}(3)$ \\
\hline Direct Control & $62,96^{\mathrm{A}}(17)$ & $29,63^{\mathrm{aB}}(8)$ & $7,41^{\mathrm{B}}(2)$ & $37,04(10)$ & $33,33(9)$ & $29,63^{\mathrm{a}}(8)$ \\
\hline Indirect Sucrose & $94,74^{\mathrm{A}}(18)$ & $5,26^{\mathrm{bB}}(1)$ & $0,00^{\mathrm{B}}(0)$ & $47,37(9)$ & $42,10(8)$ & $10,53^{\mathrm{ab}}(2)$ \\
\hline Dirct Sucrose & $88,24^{\mathrm{A}}(15)$ & $11,76^{\mathrm{abB}}(2)$ & $0,00^{\mathrm{B}}(0)$ & $64,71^{\mathrm{A}}(11)$ & $29,41^{\mathrm{AB}}(5)$ & $5,88^{\mathrm{bB}}(1)$ \\
\hline
\end{tabular}

A, B Values with capital letters within rows indicate significant difference $(\mathrm{P}<0.05)$.

${ }^{\mathrm{a}, \mathrm{b}}$ Values with small letters within columns indicate significant difference $(\mathrm{P}<0.05)$.

Concerning level of extrusion before vitrification, it was verified in all treatments more embryos with Low extrusion level when compared with those of Medium and High extrusion levels. However, within extrusion levels and regarding medium extrusion level, there was a superiority $(\mathrm{P}<0.05)$ of embryos in the group of embryos vitrified in the absence of sucrose and not subjected to cryoprotectant removal (Control Group ), compared to those vitrified with sucrose and subjected to cryoprotectant removal (Indirect Sucrose). In addition, before vitrification, it was not observed any significant difference between experimental groups for any level of extrusion (Table 3). Already after warming, only the group of embryos vitrified without sucrose and subjected to removal of cryoprotectant (Indirect Control) and the group of embryos vitrified with sucrose and not subjected to removal of cryoprotectant
(Direct Sucrose) had a higher $(\mathrm{P}<0.05)$ percentage of embryos with low extrusion. In addition, within extrusion levels and regarding high extrusion level, a significant $(\mathrm{P}<0.05)$ superiority was observed when vitrified in the absence of sucrose and not subjected to removal of cryoprotectant (Direct Control), compared to those vitrified with sucrose and not subjected to removal of cryoprotectant (Direct Sucrose) (Table 3). These data demonstrate that removing of cryoprotectant is not necessary after warm procedure when embryos were vitrified on the presence of sucrose.

Furthermore, no significant difference was observed between the groups regarding the occurrence of embryonic retraction before vitrification. Regarding percentage of re-expanded embryos, this characteristic was verified in all groups without, however, statistical difference between them (Table 4). 
Table 4. Presence or Absence of Embryo Retraction, before vitrification and and Re-expansion after warming processes of Dorper embryos produced in vivo and vitrified without sucrose and submitted (Indirect Control) or not (Direct Control) to cryoprotectant removal as well as with sucrose and submitted (Indirect Sucrose) or not (Direct Sucrose) to cryoprotectant removal.

\begin{tabular}{|c|c|c|c|c|}
\hline & \multicolumn{2}{|c|}{ Retraction before vitrification } & \multicolumn{2}{|c|}{ Re-expansion after warming } \\
\hline & Presence & Absence & Presence & Absence \\
\hline Indirect Control & $3,71^{\mathrm{B}}(1)$ & $96,29^{\mathrm{A}}(26)$ & $85,19^{\mathrm{A}}(23)$ & $14,81^{\mathrm{B}}(4)$ \\
\hline Direct Control & $18,52^{\mathrm{B}}(5)$ & $81,48^{\mathrm{A}}(22)$ & $100^{\mathrm{A}}(27)$ & $0,0^{\mathrm{B}}$ \\
\hline Indirect Sucrose & $15,79^{\mathrm{B}}(3)$ & $84,21^{\mathrm{A}}(16)$ & $100^{\mathrm{A}}(19)$ & $0,0^{\mathrm{B}}$ \\
\hline Direct Sucrose & $0,0^{\mathrm{B}}$ & $100^{\mathrm{A}}(17)$ & $100^{\mathrm{A}}(17)$ & $0,0^{\mathrm{B}}$ \\
\hline
\end{tabular}

A, B Values with capital letters within rows indicate significant difference $(\mathrm{P}<0.05)$.

a, b Values with small letters within columns indicate significant difference $(\mathrm{P}<0.05)$.

Grouping the embryos submitted to cryoprotectant removal (Indirect Control and Indirect Sucrose) and those that were not submitted (Direct Control and Direct Sucrose) and also regarding embryo re-expansion, the percentage of embryos that did not re-expand was significantly greater $(\mathrm{P}<0.05)$ in embryos subjected to cryoprotectant removal compared to embryos not subjected to cryoprotectant removal $(8.69 \%$ vs. $0.0 \%$, respectively) (Table 4 ). These data suggest that it is not necessary to remove the cryoprotectant after warm procedure when embryos were vitrified on the presence of sucrose.

The origin of embryos (produced in vivo) positively influences embryo quality (MASSIP, 2001). Embryos classified as excellent or good show a greater resistance to the cryopreservation process because they show a remarkable superiority in number of viable cells after freezing-warming and better cell metabolism (RIZOS et al., 2008). Papadopoulos et al. (2002), found pregnancy rates of $50 \%$ and $5 \%$ when they compared vitrified embryos produced in vivo or in vitro, respectively, when they were loaded in OPS straws. Dattena et al. (2000) obtained embryo survival rate of $40 \%$ and $81.2 \%$ from ovine embryos produced in vitro and in vivo, respectively.

The vitrified embryos without sucrose showed a lower quality when compared to that vitrified with sucrose at the time of warming. These data are in agreement with Guignot et al. (2006), who found kidding rates of $56 \%$ and $27 \%$ when compared vitrified goat embryos with or without sucrose, respectively. These same authors also observed a tendency to increase the embryo survival rate using sucrose. Dattena et al. (2000) obtained embryo survival rate of $40 \%$ from ovine embryos produced in vitro and vitrified with sucrose.

Martinez et al. (2002) working with bovine embryos, also observed that the addition of sucrose promoted an additional protective effect for embryos in the vitrification process. Sucrose reduces the required amount of intracellular cryoprotectants in the vitrification process (KASAI, 1996), which reduces the solution toxicity and improve the embryo quality embryo after warming. Furthermore, the sugar provides an additional osmotic effect by accelerating the cell dehydration, reducing the time available for the entry of intracellular cryoprotectants and also reducing the risk of formation of intracellular ice crystals (KASAI et al., 1990).

Thus if vitrified embryos in the presence of sucrose have shown better results regarding embryo quality grade, cell extrusion, embryo homogeneity and re-expansion rate when compared to the group vitrified without sucrose can be related to better membrane stability, the best osmotic effect and the higher protection provided by sucrose. 
The embryonic viability after warming can be influenced by age, stage of embryo development and quality (LEIBO; LOSKUTOFF, 1993) and can be evaluated by different parameters as, for example, re-expansion rate (MARTINÉZ et al., 1998).

The data of embryos subjected or not to cryoprotectant removal showed that embryos not subjected to the manipulation required to cryoprotectant removal showed better re-expansion rate. These results are in agreement with Baril et al. (2001) who showed that the vitrified embryos may be transferred directly or without removing the cryoprotectant. These same authors report that $15 \%$ to $20 \%$ of the embryos are discarded because the embryo damages attributed to excessive morphological examination performed after vitrification-warming. This shows that the morphological evaluation of vitrified-warmed embryos may not be necessary and leads to the elimination of viable embryos by excessive handling as well as that the methods used for cryoprotectant removal are less efficient than those using direct transfer of embryos. Furthermore, the using of this technique eliminates the need for a skilled technician in embryo evaluation (BARIL et al., 2001). Guignot et al. (2006) also found statistically similar values to compare vitrified goat embryos and transferred directly or indirectly, regarding embryo survival rates. Thus, the direct transfer of vitrified embryos represents a potential gain regarding lambing rate and may thereby reduces the cost of Multiple Ovulation and Embryo Transfer (MOET) in sheep.

Regarding in vitro evaluations performed after warming protocols, it was observed that the addition of sucrose to the vitrification protocol showed a significant improvement in the in vitro parameters of embryos indirectly or directly transferred.

\section{Conclusions}

In conclusion, addition of sucrose to the vitrification medium of Dorper embryos produced in vivo provides a better homogeneity and a lower extrusion grade and then enhances the quality of the vitrified embryos after cryopreservation procedure. In addition, removing of cryoprotectant is not necessary when sucrose is used.

\section{Acknowledgements}

The authors are grateful to Doctor Vicente Freitas and the Laboratory of Phisiology and Control of Reproduction for the generous supply of the laparoscopic system used at ovarian evaluation. They also thank to FACEPE - Foundation for Science and Technology of the State of Pernambuco, by the financial support of the experiment and EBDA Experimental Station of Agricultural Development Company of Bahia for providing animals and facilities for conducting the experiment.

\section{References}

ALLER, J. F.; ALBERIO, R. H.; IOVANNITTI, B.; CABOCEVILA, J. Criopreservación de embriones mamíferos $1^{\text {a }}$ parte. Características generales de La congelación. Revista de Medicina Veterinária, Buenos Aires, v. 76, n. 2, p. 132-136, 1995.

BARIL, G.; BREBION, P.; CHESNÉ. P. Manual de formación práctica para el trasplante de embriones en ovejas y cabras. Roma: FAO, 1995. 182 p.

BARIL, G.; TRALDI, A. L.; COGNIÉY, B.; LEBOEUF, J. F.; CBECKERS, P.; MERMILLOD, P. Successful direct transfer of vitrified sheep embryos. Theriogenology, Dublin, v. 56, n. 2, p. 299-305, 2001.

CROWE, J.; CROWE, L.; MOURADIAN, R. Stabilization of biological membranes at low water activities. Cryobiology, Davis, v. 20, n. 1, p. 346-356, 1983.

DATTENA, M.; ACCARDO, C.; PILICHI, S.; ISACHENKO, V.; MARA, L.; CHESSA, B.; CAPPAI, P. Comparison of different vitrification protocols on viability after transfer of ovine blastocysts in vitro produced and in vivo derived. Theriogenology, Dublin, v. 62, n. 3-4, p. 481-493, 2004.

DATTENA, M.; PTAK, G.; LOI, P.; CAPPAI, P. Survival and viability of vitrified in vitro and in vivo produced ovine blastocysts. Theriogenology, Dublin, v. 53, n. 8, p. 1511-1519, 2000. 
DUBY, R. T.; HILL, J. L.; O'CALLAGHAN, D.; OVERSTROM, E. W.; BOLAND, M. P. Changes induced in the bovine zona pellucida by ovine and bovine oviducts. Theriogenology, Amherst, v. 47, n. 1, p. 332, 1997.

GUIGNOT, F.; BOUTTIER, A.; BARIL, G.; SALVETTI, P.; PIGNON, P.; BECKERS, J. F.; TOUZE', J. L.; COGNIE', J.; TRALDI, A. S.; COGNIE', Y.; MERMILLOD, P. Improved vitrification method allowing direct transfer of goat embryos. Theriogenology, Nouzilly, v. 66, n. 4, p. 1004-1011, 2006.

HONG, Q. H.; TIAN, S. J.; ZHU, S. E.; FENG, J. Z.; YAN, C. L.; ZHAO, X. M.; LIU, G. S.; ZHENG, S. M. Vitrification of Boer goat morulae and early blastocysts by straw and open-pulled straw method. Reproduction Domestic Animals, Beijing, v. 42, n. 1, p. 34-38, 2007.

HURTT, A. E. Vitrification of equine and bovine oocytes using open pulled straws. 1999. Dissertation (Master of Science) - Colorado States University, Colorado.

ISACHENKO, V.; ALABART, J. L.; DATTENA, M.; NAWROTH, F.; CAPPAI, P.; ISACHENKO, E.; COCERO, M. J.; OLIVERA, J.; ROCHE, A.; ACCARDO, C. KRIVOKHARCHENKO, A.; FOLCH, J. New technology for vitrification and field (microscopefree) warming and transfer of small ruminant embryos. Theriogenology, Dublin, v. 59, n. 5-6, p. 1209-1218, 2003.

KASAI, M. Simple and efficient methods for vitrification of mammalian embryos. Animal Reproduction Science, Manchester, v. 42, n. 1-4, p. 67-75, 1996.

KASAI, M.; KOMI, J. H.; TAKAKAMO, A.; TSUDERA, H.; SAKURAI, T.; MACHIDA, T. A simple method for mouse embryo cryopreservation in a low toxicity vitrification solution, without appreciable loss of viability. Journal of Reproduction and Fertility, Bradley, v. 89, n. 1, p. 91-97, 1990.

LEIBO, S. P.; LOSKUTOFF, N. M. Cryobiology of in vitro-derived bovine embryos. Theriogenology, Ontario, v. 39, n. 1, p. 81-94, 1993.

LIM, K. T.; JANG, G.; KO, K. H.; LEE, W. W.; PARK, H. J.; KIM, J. J.; KANG, S. K.; LEE, B. C. Improved cryopreservation of bovine preimplantation embryos cultured in chemically defined medium. Animal Reproduction Science, Manchester, v. 103, n. 3-4, p. 239248, 2008.

MARTINÉZ, A. G.; MOTOS, D. G.; FURNUS, C. C.; BROGLIATTI, G. M. In vitro evaluation and pregnancy rates after vitrification of in vitro produced bovine embryos. Theriogenology, Stoneham, v. 50, n. 5, p. 757 $767,1998$.
MARTINEZ, A. G.; VALCÁRCEL, A.; HERAS, M. A.; MATOS, D. G.; FURNUS, C.; BROGLIATTI, G. Vitrification of in vitro produced bovine embryos: in vitro and in vivo evaluations. Animal Reproduction Science, Manchester, v. 73, n. 1-2, p. 11-21, 2002.

MASSIP, A. Cryopreservation of embryos of farm animals. Reproduction in Domestic Animals, Berlin, v. 36, n. 2, p. 49-55, 2001.

OLDHAM, C. M.; LINDSAY, D. R. Laparoscopy in the ewe: a photographic record of the ovarian activity of ewes experiencing normal or abnormal oestrous cycles. Animal Reproduction Science, Manchester, v. 3, n. 2, p. 119-124, 1980.

PAPADOPOULOS, S.; RIZOS, D.; DUFFY, P.; WADE, M.; QUINN, K.; BOLAND, M. P.; LONERGAN, P. Embryo survival and recipiente pregnancy rates after transfer of fresh or vitrified, in vio or in vitro procuced ovine blastocysts. Animal Reproduction Science, Manchester, v. 74, n. 1-2, p. 35-44, 2002.

RALL, W. F. Factors affecting the survival of mouse embryos cryopreserved by vitrification. Cryobiology, San Antonio, v. 24, n. 5, p. 387-402, 1987.

RIZOS, D.; CLEMENTE, M.; BERMEJO-ALVAREZ, P.; DE LA FUENTE, J.; LONERGAN, P.; GUTIÉRREZADÁN, A. Consequences of in vitro culture conditions on embryo development and quality. Reproduction in Domestic Animals, Dublin, v. 43, n. 4, p. 44-50, 2008.

ROBERTSON, I.; NELSON, R. Certification and identification of embryos. In: STRINGFELLOW, D. A.; SEIDEL, S. M. (Ed.). Proceedings of Guide of International Embryo Transfer Society. Savoy: IETS Publish, 2010. p. 109-122.

SAITO, N.; IMAI, K.; TOMIZAW, A. M. Effect of sugars addition on the survival of vitrified bovine blastocysts produced in vitro. Theriogenology, Stoneham, v. 41, n. 5, p. 1053-1060, 1994.

SEIDEL JUNIOR, G. E. Criopreservation of equine embryos. Veterinary Clinics of North America: Equine Practice, Fort Collins, v. 12, n. 1, p. 85-99, 1996.

Principles of cryopreservation of mammalian embryos. In: TECHNIQUES FOR FREEZING MAMMALIAN EMBRYOS: SHORT COURSE PROCEEDINGS, 6., 1986. Fort Collins. Proceedings... Fort Collins: Colorado State University, 1986.

SHAMSUDDIN, M.; LARSSON, B.; GUSTAFFSON, H.; GUSTARI, S.; BARTOLOME, J.; RODRIGUEZMARTINEZ, H. Comparative morphological evaluation of in vivo and in vitro produced bovine embryos. 12 th International Congress of Animal Reproduction, Alicante, v. 3, n. 1, p. 1333-1335, 1992. 
WERLICH, D. E.; BARRETA, M. H.; MARTINS, L.; TVIEIRA, A. D.; MORAES, A. N.; MEZZALIRA, A. Embriões bovinos PIV vitrificados em diferentes soluções crioprotetoras com ou sem o uso de nitrogênio super-resfriado. Acta Scientiae Veterinariae, Porto Alegre, v. 34, n. 1, p. 77-82, 2006. 